\title{
CONCERNING THE ORIGIN OF THE WHITE QUARTZ SANDS OF NORTHERN PUERTO RICO
}

\author{
By Janes Thorp and Leslie Rockwell Smith ${ }^{1}$
}

U. S. Dept. of Agriculture, Bureau of Chemistry and Soils, Washington, D. C.

There are numerous deposits of white quartz sands of varying depths which are distributed in belts and spots from a few miles southeast of San Juan to a point about 4 miles southeast of Quebradillas. The largest deposits occur between San Juan and Manati. Nearly every scientist who has observed these sand deposits has conjectured as to their origin and several have offered tentative theories. Most writers have merely mentioned them without attempting to offer an explanation of how they were accumulated.

The writers had the opportunity to study these white sands in great detail while making a soil survey of the districts in which they occur in abundance. We herewith submit our findings and we believe that we have been able to explain, at least in part, the methods and forces which have caused the accumulation of these deposits.

For the benefit of those unfamiliar with these sands a brief description of them and their environment is in order. The "white sand" deposits consist of white or gray quartz sands which vary in depth from a "smear" of a few inches to dune-like deposits 15 feet or more in thickness. ${ }^{2}$ Usually the surface six or eight inches of these sandy areas will be light gray colored while the subsoil will be nearly white. In many places the water table is reached at from 20 to 50 or more inches depth. In these places the white sands are

1 The authors are indebted to the Director of the Insular Experiment Station, Mr. F. A. López-Domínguez and assistants Messrs. Jorge Landrón and David Rodríguez for their helpful cooperation in the prosecution of the soil survey of the north coast which furnished the basis for much of the contents of this paper. We are also greatly indebted to Dr. N. L. Britton of the New York Botannical Garden, Chancellor Carlos E: Chardon of the University of Puerto Rico, and Dr. H. A. Meyerhoff of Smith College for valuable suggestions. Dr. C. F. Marbut, Chief, and Mr. Mark Baldwin, Inspector, of the Bureau of Chemistry and Soils furnished valuable criticism and suggestions which have greatly added to the value of the paper. Messrs. Ray C. Roberts and A. T. Sweet, of the U. S. Bureau of Chemistry and Soils; and Messrs. Juan Zalduondo and Fernando A. Villamil of the Insular Experiment Station furnished soil maps of the San Juan district which were of great use in studying the distribution of white sands in that region.

2 Cook and Gleason (3) in their "Ecological Survey of Puerto Rico", published in the July, 1928, issue of the Journal of the Department of Agriculture of Porto Rico, describe the white sands in part as follows: "The soil is composed of white, calcareous (italics ours) sands of unknown depth." As a matter of fact these white sands are practically pure quartz and their acid reaction demonstrates that they are distinctly non-calcareous. Possibly the sands were confused with nearby shell sands which are highly calcareous. It is commonly believed among the farmers of the northern coastal region that these sands consist of limestone grains. 
underlain by a heavy, columnar and highly acid clay which is exceedingly difficult to penetrate with digging tools. This clay is usually gray in color with streaks and blotches of bright red or yellow or both. The thickness of the clay varies and is known to be more than 15 feet deep in places. The cracks and root holes are usually lined with white leached clay (probably kaolin). The sand, where it contacts the clay, is usually stained dark brown or dark gray and is often cemented into a "hardpan". Superficial observation would lead one to believe that this cementing material consists of iron oxides (limonite) but if the "hardpan" is ignited the dark color disappears and leaves a white or sometimes a pale yellow sand. It is evident, therefore, that the cement is of organic material. In a few places it was observed that the hardpan layer was partly of iron and partly of organic material. When the hardpan from these latter places is ignited the organic part of the cement burns out and the residue, owing to the effect of iron oxide, assumes a light red or or pinkish color.

The underlying clay material, when it is exposed in a ditch bank or road eut, exhibits a strong tendency to form vertical columns. These columns break up into well defined prisms of varying sizes which are very hard when dry and exceedingly stiff and resistant to pressure when moist. In the wet condition a good degree of plasticity develops.

There are many places where the white sands lie on knolls or on gently sloping hillsides and a few places where the slope is quite steep. At first sight one would expect that the natural drainage would be good or even excessive in these places. This is frequently true but in many apparently well drained areas there is a heavy, tight clay like that described above which holds up the descending waters after rains and eauses the lower layer of white sands to be wet much of the time. In these places, just as in those described in the foregoing an organic hardpan forms. The places where the white sands have good subdrainage do not have well developed organic hardpans and in some places even dark organic stains are lacking.

Where the white sands are deep they tend to blow up into low dunes and to spread out into layers of varying thickness over adjacent soils. In places where the latter has occurred one does not, of course, find the normal profile development.

All of the sands observed occur within the belt of land where the Tertiary limestone forms the bedrock. Britton (1), Chardón and others have suggested that these sands may be the residuum left 
from the weathering of these limestones. There is much evidence to support this hypothesis. The Tertiary limestones have been weathered in a manner peculiar to the tropical regions. Except for small areas where the large rivers have cut their way through from the interior of the island, surface alluvial erosion is negligible. Underground streams remove most of the water which falls on the Tertiary limestones and these streams are fed by water which seeps down through the porous limestone and sinkholes. Differential solution of the limestones has led to the formation of myriads of "solution valleys" and intervening "mogotes", "pepino" (cucumber), or "haystack" hills. These "haystack" hills are closely spaced in places and in other places stand out in isolated groups or in rows in the larger open valleys.

Where the white sands occur in "solution valleys" which are entirely surrounded by high hills there is no other probable source for them than the limestone itself. There seems to be little if any doubt that this is the ease. The writers, with this in mind, made a large number of observations to see whether the limestones contained quartz sand in sufficient quantities to account, not only for the white sands but also for the sands which occur in the valley soils which are red, brown, or yellow in color. It was found that there are many layers of limestone which contain more or less sand and there are a few thin interstratified layers of clays and sands which contain little or no lime. Dr. Britton (1) once observed sandy layers in the limestones near San Juan and our more extensive observations have confirmed his findings. Places where these sandy layers may be easily observed are in the vicinity of Almirante; six miles southwest of Arecibo on the Lares road; 4 and $1 / 2$ miles southeast of Hatillo; and on the Camuy River trail 5 and $1 / 4$ miles southeast of Camuy, 300 yards before the river is reached. In the latter place there is a 3 or 4 foot thickness of limestone which, perhaps, contains as much as 30 per cent of quartz sands. A sample of decayed limestone from 4 and 1/4 miles southeast of Hatillo was examined by Fry of the U. S. Bureau of Chemistry and Soils and he estimated that it contained 25 per cent of quartz sand. The sandiest soils of limestone derivation and the areas of white sand were observed in the localities where it was definitely determined that the limestones contained appreciable quantities of sand. This is by far the most plausible explanation of the origin of the white (and other) sands of the localities which are remote from the seacoast. The dissolving of great thickness of these limestones would readily account for the accumulation of sands in the "solution valleys". It might be observed in passing 
that the sandy limestones occur in the transition zone between the youngest of the Tertiary beds and the second youngest. These different divisions have been described by Hubbard (5), Meyerhoff (9) and others. Meyerhoff ${ }^{3}$ suggests the possibility of artesian springs bringing up the sands from underground, but we observed no place where this would seem to be a plausible explanation.

The largest beds of white sands occur fairly near the seacoast at distances varying from $1 / 2$ mile to 2 and $1 / 2$ miles. The limestone hills between them and the ocean are often quite low and rounded and in many places it seems quite possible that sands from the beaches may have been blown over the hills by the prevailing northeast trade winds. One of the largest deposits occurs 1 and $1 / 5$ miles southwest of Arecibo. In this place the sands occur intermittently over a large U-shaped area the two arms of which extend in a west-southwest direction. Over most of this area the sands lie on a nearly common level and comprise flattish bench-like deposits. Numerous deep sinkholes indent this flattish area and it is surrounded by lowlying, rounded limestone hills. A few of the white sands in this district are on the tops of low rounded knolls and above the average level of the main body. The sands of the northern arm and eastern end of this area grade into acid brown sands which are frequently underlain by heavy clay subsoils similar to those under the white sands. Several large areas of the brown sands have a sandy iron hardpan layer between the soil proper and the subsoil. These acid brown sands, in turn, grade into alkaline brown quartz sandy soils as the coast is approached. These latter sands are without doubt largely derived from the disintegration of the San Juan consolidated sand dunes the sands of which are being broken apart by the waves on the seacoast and spread inland by the trade winds. It should be remarked for the benefit of those not familiar with the San Juan sand dunes that they were originally piled up by the trade winds on a bar near the shore and have subsequently been cemented by lime. This cement was very probably formed by a deposition of lime which resulted from the evaporation of sea spray. Some of the lime may also have come from the solution and redeposition of the lime of sea shell fragments. Probably the acid brown sands which are farther inland than the alkaline sands were largely derived from the sands which have spread inland from the coast through the agency of wind. They are acid because the leaching of the lime in them

${ }^{3}$ In 1931-32, Dr. H. A. Meyerhoff of Smith College, delivered a series of lectures at the University of Puerto Rico. These lectures are to appear in book form at an early dato and their author very kindly permitted us to read the manuscript. 
has exceeded the rate at which the limy material from the coastal sands has been supplied. At the present time there is very little transportation of material taking place because of the fact that grasses and bushes are holding the sand in place.

It may be readily surmised from the above that at least a part of the white sands near Arecibo have been derived from brown sands which have been blown inland from the coast. The present pale gray or white color is due to excessive acid leaching by ordinary soil forming processes. These processes will be discussed later in greater detail.

Another possible explanation of the presence of a large body of white and gray sands near Arecibo is that there may have been an old lake, swamp or estuary in this locality and the sands may have been deposited along its shores or on the bottom. A deposit of white șands now borders Laguna Tortuguero farther to the east. The great thickness of heavy mottled clay under the white sands lends credence to this theory. Another evidence to lend support to the theory of an old estuarine or lake deposition is the fact that it is well known that the coast line between Arecibo and Aguadilla has been much lower in the past. High wave-cut terraces are to be discussed in Meyerhoff's "Geology of the Arecibo District" so we shall not discuss them further here.

In many places between Manatí and San Juan the deposits of sand are very deep and in many of these places there is unquestionable evidence that they have been reworked by the wind since original deposition.

Between San Juan and Carolina there are deposits of white sands surrounding swampy and mucky areas where the evidence seems to be in favor of lagoon shore deposition. Granting the idea of some of the sands having been old beaches we still may be permitted to wonder from whence the sands were originally derived. We may still logically suppose that a fair share of them came from the dissolution of the Tertiary limestones and perhaps a part of them from the weathering of the nearby San Juan formation. If we must go back to first beginnings the quartz grains doubtless came from the weathering of granites and other siliceous rocks of the "oldlands" of the interior. The rivers carried the sands down and the waves and eurrents spread them out over the Tertiary sea when the limestone strata were being built up.

Up to the present point in our discussion we have devoted our remarks almost entirely to the explanation of the different probable sources of the white sands with scarcely any mention of why they 
are white instead of brown, yellow or red like the other sands with which they are closely associated. The answer to the latter question is one which may be best referred to soil science. Soils quite similar to the white sands of Puerto Rico oceur abundantly in the southeastern coastal plains of the United States. They are especially abundant near the Atlantic seacoast in Georgia and Florida but occur in scattered localities somewhat farther north than Lakewood, New Jersey. The areas of white sands in Puerto Rico which have a high water table are very much like the León and related sands of the coastal plains of Georgia and Florida, while the deeper sands are much like the St. Lucie soils of Florida. The shallower types, which are well drained, resemble the Lakewood sands which are distributed from New Jersey well into the southern states. Hearn (4) estimates that there is a total area of about 4 or 5 million acres of the León sand alone. This is about twice the total area of Puerto Rico. The Lakewood and St. Lucie soils in their turn oceupy a tremendous additional area. Cobb (2) observed similar sands in France and Bennett found a few areas of León sands in Nicaragua. It should be plainly understood at this point that there are several minor points of difference between the different types of white sands in Puerto Rico and the similar types on the United States mainland. We cannot, therefore, call them by the same names. Soils of the León series are characterized by a dark gray, strongly acid, sandy surface about 4 inches thick, about 18 inches of white quartz sand and a 10 inch organic hardpan just above the water table which occurs at about 32 inches from the surface. Beneath the hardpan there is normally a loose wet yellowish sand to considerable depths. In some places, however, the hardpan is underlain by a stiff mottled clay just like the clay layer underlying much of the Puerto Rico white sands. The deeper white sand deposits of Puerto Rico more closely resemble the St. Lucie sand of Florida which consists mainly of a loose, white quartz sand to great depths. This sand also has an organic hardpan or at least streaks of dark organic matter at or near the water table level if the latter occurs within the sand itself. It may be easily seen from the foregoing that white sands similar to the sands of Puerto Rico are very well known indeed in other parts of the world.

The general processes by which soils of this type are formed are well known. Marbut (6) speaks of the León sands as "ground water podzols" and of the Lakewood sands as true podzols. Typical podzols or "ashy gray" soils are formed in well drained areas under a humid climate and usually under a conifer forest cover. They are characterized by a surface mulch of semi-decayed organic debris such 
as pine needles, leaves, rotten wood, etc.; an ashy gray or nearly white "leached horizon"; a B-horizon or accumulated iron, clay and organic matter and the underlying parent rock. "Ground water podzols", such as the poorly subdrained types of white sands in Puerto Rico, usually occur only where the parent materials are originally very sandy and where the water table is relatively high, or in other words, where subdrainage is very poor. Until quite recently it has been believed by most soil scientists that true podzols can be formed only in a cool temperate region but Marbut (6) has shown that the Lakewood sand is a true podzol and it extends well into the warm temperate regions of the south. It is significant, however, that only the very leachy sandy soils have thus far been proved to form typical podzols outside of cool temperate regions. True podzols derived from heavier materials, have been thought to be confined largely, if not entirely, to humid cool temperate regions, either in high latitudes or at high altitudes in low latitudes. Abundant evidence of podzolization in many parts of Puerto Rico from sea level to 3,000 or more feet above the sea, have proved that the process is active here and it is possible that small areas of true podzols from heavier materials than sands may be discovered. A bit of evidence along this line will be discussed later in this paper.

Probably much more than half of the white sands of Puerto Rico are "ground water podzols". Hearn (4) in a paper read before the eleventh annual meeting of the American Soil Survey Association, November, 1930, has given a good review of the formation of the León type of soil profile, which so closely resembles the ground water podzols of Puerto Rico. He laid special emphasis on the formation of the organic hardpan, which, before analyses were made, was thought to consist of oxides of iron. Briefly, the original material is very sandy and contains only very small percentages of silts and clays. The silts and clays are removed by the downward percolation of meteoric waters. This process is known as "eluviation" and it is aided and hastened by the colloidal organic acids produced by the decay of plant remains. These acids act as solvents for colloidal iron stains which lend ordinary quartz sands a red, yellow or brown coloration, with the ultimate effect of bleaching the sands white. Colloidal organic matter is formed by the work of bacteria which cause the decay of dead roots and leaves of plants in the soil proper. Much of this material is precipitated at the level of ground water forming the organic hardpan. The mass of hardpan is greatly increased by the presence of plant roots which accumulate at the level of ground water. In the southeastern states one of the commonest 
plants is the sawtooth palmetto and its roots have been observed to be concentrated in the hardpan. On some of the white sands of Puerto Rico the corozo palm is quite common and it is quite possible that its roots, as well as those of other plants, have contributed to the hardpan.

We may then offer the following suggestions as to the formation of the poorly drained white sands of Puerto Rico. First we start with a soil material which contains a very high to fairly high percentage of silica sands. This sandy soil will lie in a fairly flat position and must either contain an impervious layer beneath or must contain material which may later be used by the soil forming processes to cause conditions of poor drainage. Poor drainage may, of course, also be caused by a high water table which has been brought about by proximity to sea or lake level. There must be some vegetation to furnish organic material to be used by the soil in forming acids, and there must finally be a humid climate to furnish the necessary leaching waters.

In the case of the largest deposits of the sands the original material seems to have been derived partially as a residuum from dissolved slightly arenaceous limestones and partly a subaerial accumulation of sands which have been earried inland from the wave-shattered San Juan sandstone formation. There is some evidence that some of these sands are littoral deposits which have remained after a slight withdrawal of water of the sea and lagoons in recent geological times. It seems almost certain that these larger deposits of sandy materials were locally transported by wind or water or both and deposited on the gray clays of lowlands possibly formerly occupied by lagoons, estuaries or sinkhole ponds. This gray clay furnished the necessary conditions of poor drainage. Vegetation occupied the soil and the leaching of the minor amounts of silts and colloidal materials proceeded at a rapid rate. In many places, typically a short distance southwest of Arecibo, there is a regular transition from highly leached white sands, through gray-brown acid sands to alkaline sands, proceeding toward the seacoast. All of the white sands are far enough from the sea to be almost entirely unaffected by the spray from the breaking waves which are piled up by the trade winds. Soils in this district so affected are universally alkaline in reaction. In such a leaching process any soluble salts disappear first, then the less soluble calcium carbonate and finally, after the decaying organic matter lends an acid condition to the soil, the other soil pigments are dissolved and carried out by the ground water. The poor drainage causes the iron to be reduced to the fer- 
rous state which makes it much more soluble. In places where the parent sands contain larger amounts of iron and alumina than normal these materials are mixed with the hardpan.

The above description of the formation of white sands covers a very large total area of these soils. Many places having apparent good drainage, if one were to judge by surface appearances, in reality have a fairly high water table which usually lies just above the heavy clay layer. It is probable that most or all of the sands of these places should be classed as ground water podzols. There are many other places, however, where subdrainage as well as surface drainage is sufficiently good to throw the white sands into the class of true podzols which form only under normally good drainage conditions. Until very recently it had been considered by most soil scientists that it is very improbable that true podzols would be found in tropical lowlands. Marbut ${ }^{4}$ and Affanassief and others have found evidences of podzolization in the tropical lowlands and they have predicted the possibility of the existence of true podzols in this position. We are unaware of such podzols having actually been found in tropical lowlands until last year when the white sands of Puerto Rico were thoroughly studied in the field. From a morphological standpoint the well drained white sands which we shall briefly describe below are unquestionably true podzols in the same sense that the Lakewood sands of New Jersey are true podzols. We fully expect that chemical analyses will confirm the morphological identification.

- If the process of true podzolization is to account for the formation of the well subdrained areas of white sands it would be reasonable to suppose that the same types of deposit might be formed from different materials with different thicknesses of the product and with a large number of gradations between the typical white sands and other soils with which they are associated. One type of such gradation has already been mentioned. In those deposits occurring well within the limestone hills and several miles distant from the seacoast one of the commonest associations of white sands is with a group of soils known provisionally as the Vega Alta series. This series of soils has grayish brown surface soils with compact but moderately well drained, coarsely mottled red, yellow and gray subsoils, the former two colors predominating. The heavier types of this series, such as the clay and clay loam are more brown than gray in the surface but the sandier types become grayer with the increase in the percentage of sand present. In many cases the soil surveyor is puzzled as to whether to group these grayer sandier types of soils with 
the Vega Alta series or with the shallower types of the white sand group. With the graying of the surface horizon there is sometimes a tendency for the subsoil to become more poorly drained. This change in the drainage conditions seems to have been brought about by the eluviation-illuviation process. The clays and colloids have been eluviated from the surface by meteoric waters and deposited in the interstices of the subsoil forming a layer of illuviation. This process slows up drainage and may in many eases ultimately result in the formation of a temporary shallow water table at which an organic hardpan begins to form. This gives rise to the ultimate formation of the ground water podzol type of white sand. On the other hand there are many places where the subsoil retains sufficiently good drainage to take care of the meteoric waters. One such area lies some distance south of Sabana Hoyo far within the limestone hills in association with soils of the Vega Alta series. It has the grayish white surface and white upper subsoil but lacks the organic hardpan. The underlying clay is typical of the Vega Alta series of soils and is therefore well drained. The upper subsoil, as in the case of the Vega Alta soils, has accumulations of iron and alumina in addition to small amounts of colloidal organic matter. The area occurs on the top of a sharp knoll and is unquestionably a typical sandy podzol. There are several small areas like this one southwest of Arecibo and scattered elsewhere throughout the northern coastal region in association with ground water podzols. Gradations between true podzols and the sandier types of the red Bayamón and Espinosa soil series are quite common. These red soils also grade into the ground water podzols. The very deep areas of white sands usually are more or less piled up by the trade winds and since they are so loose and dry in their upper horizons it is frequently impossible to determine whether they have water in the lower horizons and whether they have developed organic hardpans. It is altogether probable that part of these deep areas belong to the true sandy podzols and part to the ground water podzols. From the standpoint of agriculture or of commercial use of the sands this problem has no bearing. It is a matter of purely scientific interest.

While we are discussing the sandy podzols it might be of interest to add a further word regarding podzolization in Puerto Rico. A very large total area of soils in the lowlands as well as in the highlands exhibit strong morphological evidences of this process. Many of these areas are of the heavier type of materials such as silts, sandy clays and perhaps clays in places. An extreme example of such soils very recently observed on a low hill near the new pier at Mayagüez 
is a silt loam with most of the morphological characteristics of a true podzol. We can at least be safe in saying that it is a very strongly podzolized soil. Rainfall is about 80 inches per annum and natural drainage is good. A description in outline form follows. It should be noted that the land has been cleared so that the original leaf mould has been destroyed.

\begin{tabular}{|c|c|c|}
\hline Horizon & Depth & Description \\
\hline $\mathrm{A}_{1}$ & $0^{\prime \prime}-4^{\prime \prime}$ & $\begin{array}{l}\text { Light brownish gray silt loam when dry. Pale } \\
\text { yellowish brown when wet. Medium gran- } \\
\text { ular structure. }\end{array}$ \\
\hline $\mathrm{A}_{2}$ & $4^{\prime \prime}-10^{\prime \prime}$ & $\begin{array}{l}\text { When dry grayish white; when wet pale yel- } \\
\text { low floury silt loam. No evident structure. }\end{array}$ \\
\hline B & $10^{\prime \prime}-30^{\prime \prime}$ & $\begin{array}{l}\text { Heavy reddish brown and yellowish brown } \\
\text { clay containing many tuff and shale frag- } \\
\text { ments. Very stiff when moist. All surfaces } \\
\text { of cleavage planes are light gray and silty } \\
\text { and gray silt follows root channels. }\end{array}$ \\
\hline C & $30^{\prime \prime}$ down. & $\begin{array}{l}\text { Loose subangular gravels of tuffs, shale and } \\
\text { cherty fragments. Possibly an old terrace } \\
\text { remnant or elevated beach line. }\end{array}$ \\
\hline
\end{tabular}

This area is very small but we believe it to be a significant evidence of the progress of podzolization at low elevations in the tropics. It is of interest to know that this highly podzolized soil occurs within two miles of the largest body of typical ferruginous laterite in Puerto Rico. A number of other places having very similar soils have been observed and it is hoped they may be discussed more fully in a later contribution. We return to the white sands after this short digression.

These white sands in their present position must be considered as very recent deposits from the standpoint of geology. They are certainly younger than the San Juan formation since in no place observed do the San Juan sandstones overlap them. Recent as they are geologically, they are quite old from the soils standpoint. The age of a soil is not measured by the number of years since the weathering forces first started working on its parent material but by the degree of leaching and eluviation which have taken place. An old soil is one in which leaching and eluviation are far advanced. In the case of sands this ean take place in a much shorter time than with soils of heavier texture or with those which are high in lime. It is certain that these "old soils" (the white sands) are younger in years than many of the "young soils" of Puerto Rico many of which are so highly valued by the farmers. 
It is interesting to notice that there are no white quartz sands west of the Río Guajataca, at least not in the north coastal belt. There are plenty of brown quartz sands which would theoretically be capable of weathering into the white variety but this weathering has not taken place. There is a good reason for this. The rainfall from Camuy to the northwestern corner of the island averages considerably less than 60 inches per annum. A rainfall of 55 inches in Puerto Rico is approximately the dividing line between a humid and a semi-arid climate. Such a rainfall in this part of the tropies might at least be designated as sub-humid. The formation of large areas of white quartz sand requires the leaching effects which can be produced only by a humid climate, hence the disappearing of these deposits in the northwestern part of the island.

A few miles southeast of Humacao large quantities of loose, fine quartz sands and gravels have been washed from nearby quartzdiorite hills and deposited on the sea level estuarine clays of the Río Candelero delta. These very recent deposits have already begun to show signs of leaching under the influence of a heavy rainfall and poor underdrainage. The sands and gravels are changing from brown and yellowish brown to a pale yellowish color. Incipient organic and iron deposits near the level of ground water prognosticate a future development of hardpan similar to that in some of the white sands we have been discussing. The entire island has not yet been covered in detail and it is reasonably possible that very small depos. its of white or gray sands somewhat similar to those of the north coast will be found in the humid regions which have not been thoroughly explored.

\section{SUMMARY}

The origin of the large deposits of almost pure white quartz sands which occur within the area occupied by the Tertiary limestones of northern Puerto Rico have long been a source of puzzlement to geologists. The largest areas occur within a mile or so of the seacoast in association with Tertiary deposits but are unconformable with them. Many of them are found in association with the remnants of lagoons which were cut off from the sea by the San Juan formation. Some deposits are also in fairly close association with the latter formation in some places. Smaller areas occur well within the limestone hills.

Examinations of limestone outcrops and of residual soils within the limestone hills indicate that a large amount of sand originally came from the solution of layers of impure limestone which formerly 
overlay the district. It is altogether probable that some of the sands have been blown inland from the broken up San Juan formation and later leached of their lime. There is some evidence to support the theory that some of these sands may have been left in or near their present position along the shore of former lagoons which have since been drained by a slight emergence of the coast. There is but little question but that the smaller deposits several miles inland and well within the limestone hills are the residuum left from the dissolution of the limestones.

The whiteness and purity of the sands are due to the soil forming process known as podzolization (acid leaching and eluviation) which in this ease has taken place largely under conditions of high rainfall and poor subdrainage and to a less extent under well drained conditions. Some of the deeper deposits which are now well drained have been more or less piled up by the winds since they were bleached. We can therefore state with reasonable assurance that the quartz sands have come from the various sources above mentioned but that they are white because of a high degree of "podzolic" leaching which has affected them sinee they accumulated. Millions of acres of similar soils which have been carefully studied by soil scientists in the southeastern United States have furnished the evidence for this explanation of the origin of Puerto Rico's white sand deposits.

\section{BIBLIOGRAPHY}

1. Britton, N. L. Las Arenas de las Planicies de la Costa Norte de Puerto Rico. Revista de Agricultura de Puerto Rico 12:157, 158. March 1924.

2. Cobb, Collier. Lands and Dunes of Gascony. Journal of the Elisha Mitchell Society. November 1910.

3. Cook, Melville T. and Gleason, Henry Allen. Ecological Survey of the Flora of Porto Rico. The Journal of the Department of Agriculture of Porto Rico. 12:3-139. July 1928.

4. Hearn, W. E. Development of the Hardpan Layer in the León Soils. Report of the 11th Annual Meeting of the American Soil Survey Association, pp. 128-136. 1931.

5. Hubbard, Bela. The Geology of the Lares District, Porto Rico. Scientific Survey of Porto Rico and the Virgin Islans, 2 (part 1) : 1-115. New York Academy of Sciences. 1923.

6. Marbut, C. F. Soils, Their Genesis, Classification and Development (Mimeographed). Lectures delivered in the U. S. Dept. of Agriculture Graduate School. Lecture 18, pp. 4 and 5. 1928.

7. Comments on the Lateritic Soils in Cuba, and the Amazon Valley. Proceedings and Papers of the Second International Congress of Soil Science, Commission and Classification Geography and Cartography of Soils, pp. 79 and 80. 
8. Marbut, C. F. and Manifold, C. B. The Soils of the Amazon Valley, etc. The Geographical Review. 15(3): July 1926.

9. Meyerhoff, H. A. Geology of the Fajardo District, Porto Rico. Scientific Survey of Porto Rico and the Virgin Islands 2 (part 3) : 201-360. New York Academy of Sciences. 1931.

\section{Explanation of Plates}

PLATE IV

Figure 1. Area of white sand southwest of Arecibo. Vegetation consists of second growth of icaco (Chrysobalanus icaco L.) and pajuil or cashew-nut (Anacardium occidentale L.) Young cocoanut trees grow very slowly on these infertile sands.

Figure 2. Upper part of profile of white sand. Grayish surface soil slumped into pit at left center. White horizon shows plainly just under plant roots at extreme left.

\section{PLATE V}

Figure 1. Shows heavy sandy clay which underlies many of the areas of white sands. Light colored vertical and horizontal streaks are white kaolin. Dark colored layer above is organic hardpan.

Figure 2. Highly podzolized soil profile about 4 miles south of Humacao. Soil is derived from quartz diorite and occurs near a hill top. Drainage good. Note strong development of whitish $\mathrm{A}_{2}$ horizon just above heavy $\mathrm{B}$ horizon at center of photograph. Profile similar to the one described from Mayagüez and represents same soil-forming process which caused the formation of the white sands. 


\section{PLATE IV.}

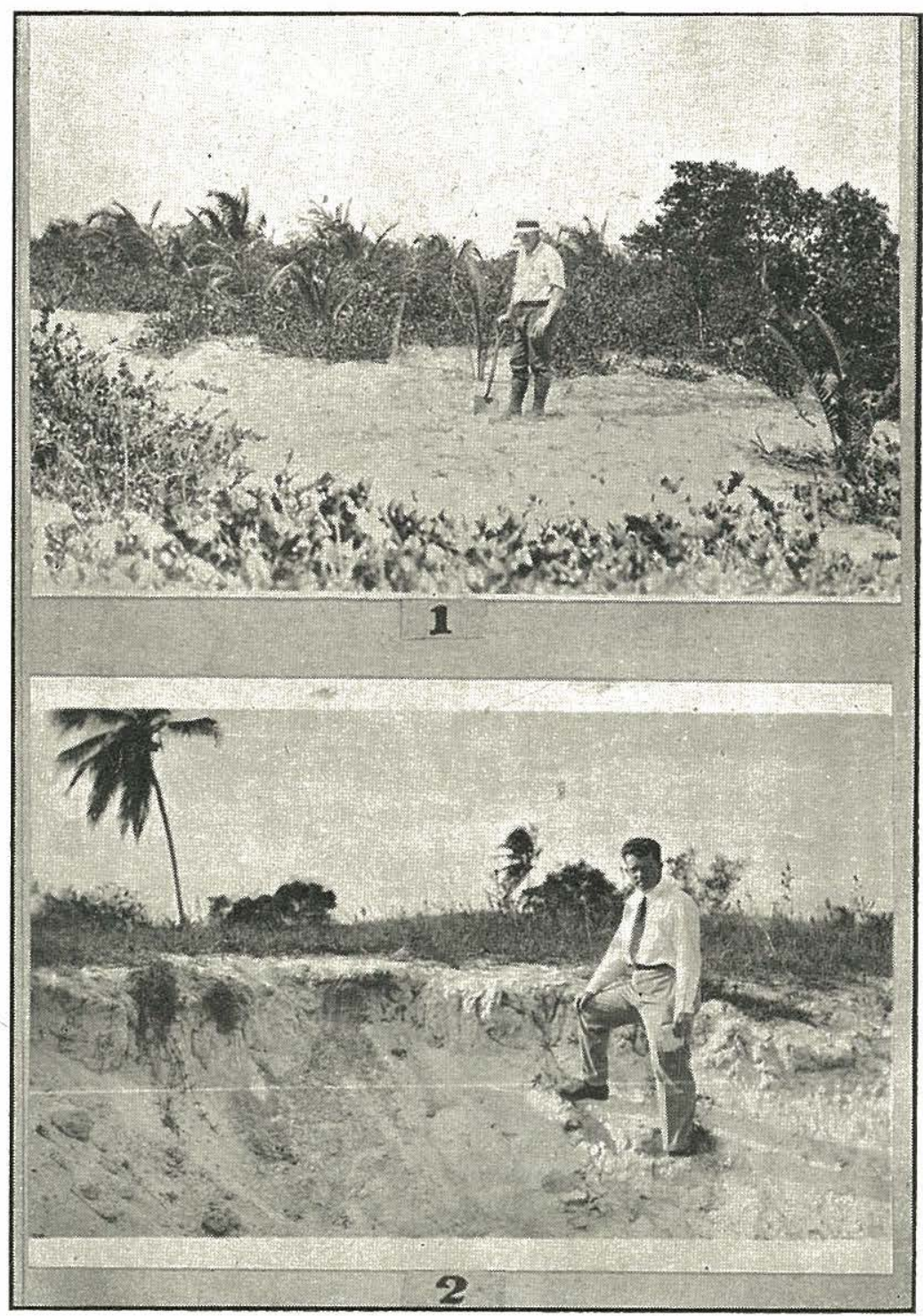




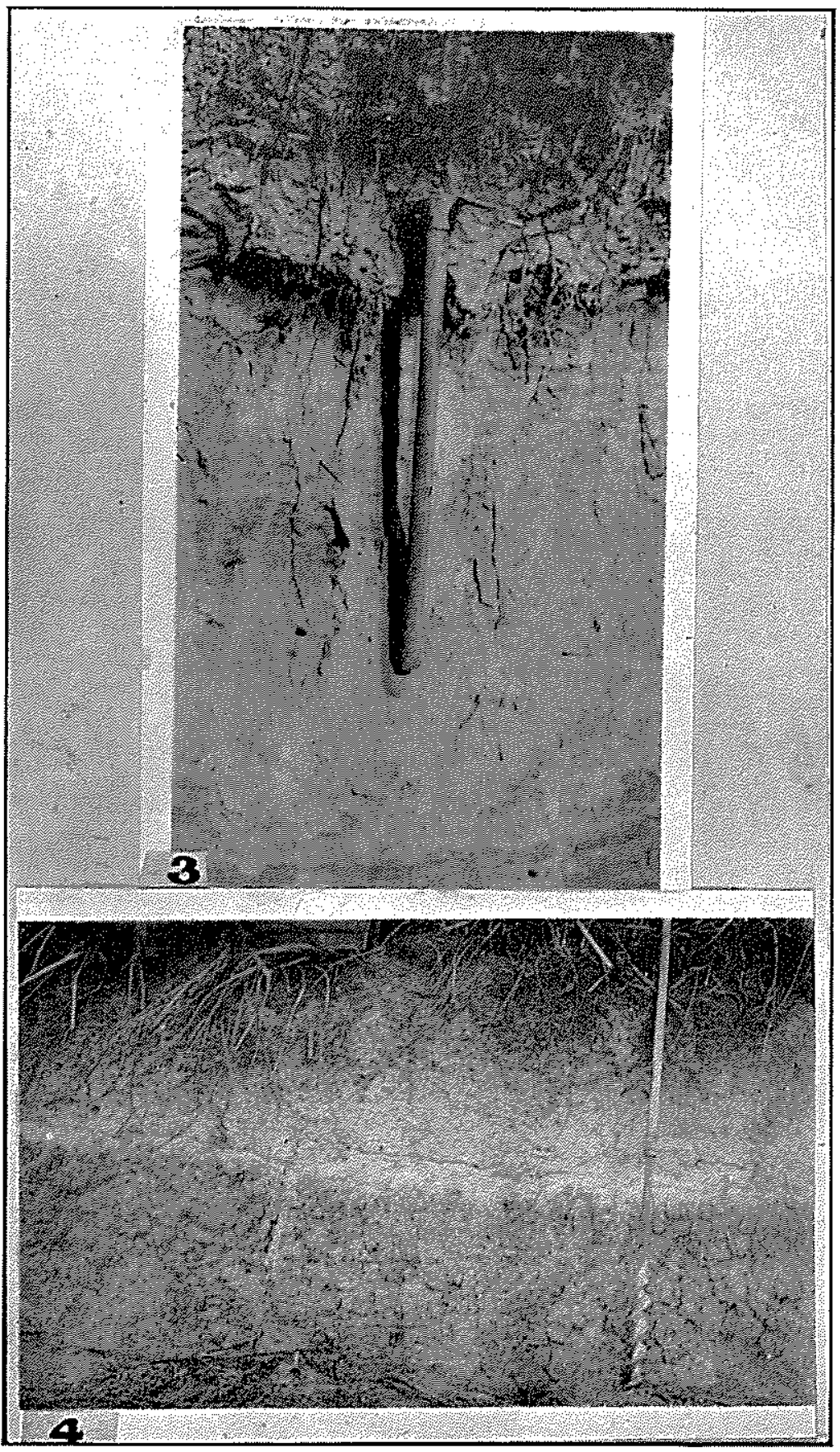

